\title{
CLIMATE INFLUENCE ON RADIAL INCREMENT OF OAK (QUERCUS SP.) IN CENTRAL POLAND
}

\author{
AGNIESZKA BRONISZ, SZYMON BIJAK, KAROL BRONISZ and MICHAL ZASADA \\ Department of Dendrometry and Forest Productivity, Warsaw University of Life Sciences - SGGW, \\ Nowoursynowska 159, 02-787 Warszawa
}

Received 16 November 2011

Accepted 20 April 2012

\begin{abstract}
The study investigates the influence of climate conditions on radial increment of oak, with special concern to the situations when analysed trees formed conspicuously wider or narrower treerings. The research material was collected in four locations in central Poland within natural range of pedunculate and sessile oaks. The elaborated residual chronologies were correlated with CRUTS 2.1 climate data. The analyses included thermal and pluvial conditions spanning from April of the year prior to ring formation to September of the current growth year. Special interest was paid to simple water ability index that combined both temperature and precipitation during the vegetation season. Additionally, pointer year analysis was carried out to determine situations when conspicuously smaller or larger increment was formed.

Investigated chronologies cover the period of 1927-1992 (Łochów), 1845-1992 (Płońsk), 1868-1992 (Pułtusk), and 1796-1992 (Sokołów). The analysed oaks from sites in central Poland exhibit growth patterns comparable with those known form previous studies concerning that species, where influence of precipitation (higher and positive) and temperature (negative) have been observed. Extreme growth reactions expressed by negative and positive pointer years turned to present high dependence of analysed oak' growth on water availability during vegetation season.
\end{abstract}

Keywords: Dendrochronology, oak, climate influence, Poland.

\section{INTRODUCTION}

Genus oak (Quercus sp.) consists of many individual species of different morphology, biology and ecology. There are three native oak species in the territory of Poland: pedunculate oak (Quercus robur L.), sessile oak (Quercus petraea Liebl.) and downy oak (Quercus pubescens Willd.) (Boratyńska et al., 2006). The last occurs in Poland only at one site and hence it is rather of botanical importance. That is why it was not included in the presented analysis. Pedunculate and sessile oaks (Fig. 1) are im-

Corresponding author: A. Bronisz

e-mail: agnieszka.bronisz@wl.sggw.pl portant from the ecological and economical point of view and are widely used in forest production in Poland.

Oak wood is very hard and durable and because of that it has been utilised as a construction material for a long time. This results in a wide use of that genus in dendrochronological research. So far a couple of hundreds of oak chronologies have been constructed, covering various time spans (Ważny, 2006).

Climate influences the tree growth process in great measure. Pace and intensity of tree-ring formation is shaped by different weather elements such as temperature, precipitation and moisture availability, sunshine duration or even snow abundance (Fritts, 1976; Schweingruber, 1996). Understanding these relationships is crucial, in 


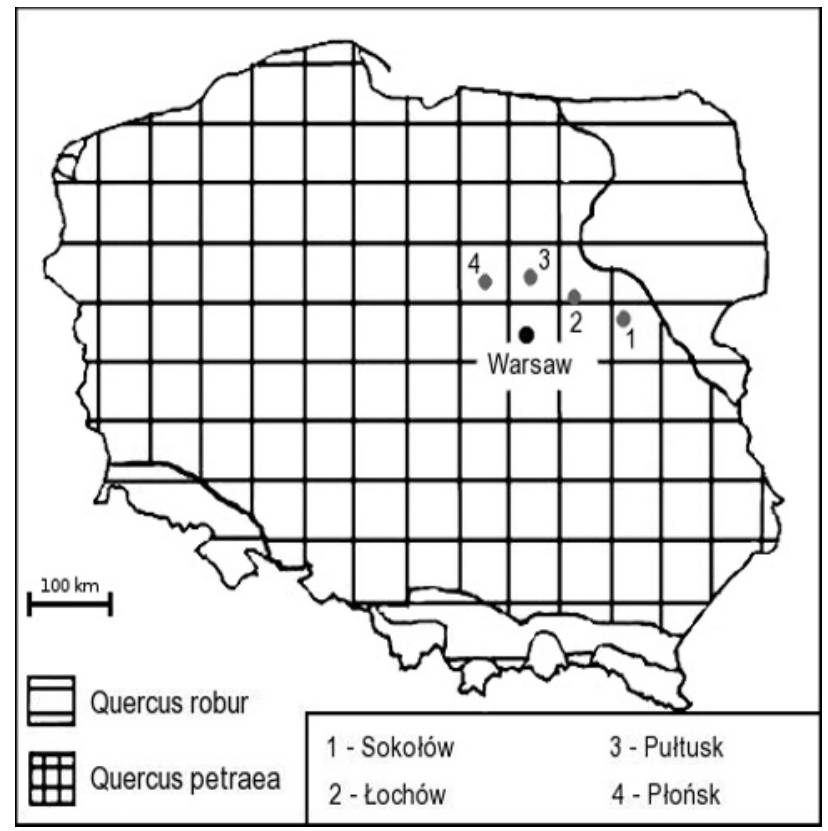

Fig. 1. Location of the study sites (dots with numbers) and natural distribution range of Quercus robur and Quercus petraea in Poland.

particular for the forest production, especially in the context of the observed ongoing climate changes.

For example, cambium cells begin their activity in spring yet before the buds burst (Ermich, 1959). Formation of new vessels proceeds thanks to supply resources gathered before. Climate conditions of both: current and previous growing seasons, are very important as onset of cambium activity depends mostly on temperature, while the process of tree-ring formation is usually controlled by precipitation.

Impact of climate on the growth of oaks was a subject of many studies across Europe and Poland following the abundance and importance of that genus. Several dendrochronological standards were elaborated and their relationships with climate conditions were studied. Influence of temperature, precipitation and other climatological parameters on various characteristics of radial increment of oaks in Europe was studied e.g. by Gray and Pilcher (1983); Santini et al. (1994); Rozas (2001) and Lebourgeois et al. (2004). Polish studies concerning that species include studies by Bednarz (1987); Ważny (1990); Bendarz and Ptak (1990); Ważny and Eckstien (1991) or Krąpiec (1998; 2001). More recent investigations focus on oaks' extreme increment reactions and their climate driving factors (Boryczka et al., 2007; Bijak, 2009).

Dendrochronological studies on oak growing on dry sites in Central and Southern Europe showed positive correlation between tree-ring width and early summer precipitation, while a negative correlation was seen between high summer temperature. These studies could be the base of the thesis that oak will suffer because of summer drought (Pilcher and Gray 1982; Van der Werf et al., 2007). This is one of the reasons of oak decline in Europe during last decades (Bednarz, 1994; Siwecki, 1994; Methy et al., 1996; Vanini et al., 1996; Bruchwald and Dmyterko, 1999; Desprez-Loustau et al., 2006).

The objective of the current study was to investigate the influence of climate conditions on radial increment of oaks (Quercus sp.) growing in central Poland with special concern to the situations when analysed trees formed conspicuously wider or narrower tree-rings.

\section{MATERIAL AND METHODS}

\section{Study sites}

The research material was collected in Polish State Forests within the territory of Łochów (mean age 56 years, 18 trees sampled, 167-172 m a.s.l.), Płońsk (mean age 60 years, 46 trees sampled, 107-145 m a.s.l.), Pułtusk (mean age 59 years, 11 trees sampled, $84-99 \mathrm{~m}$ a.s.l.) and Sokołów (mean age 58 years, 62 trees sampled, 139-169 m a.s.1.) forest districts (Fig. 1). The study sites were located in stands where oak covers between $6 \%$ (Łochów) and 20\% (Sokołów) of the forested area. The climate of the analysed area can be described as a transitional one, however continental features, i.e. hot summers and severe winters, prevail. Mean temperature in January equals $-2.2^{\circ} \mathrm{C}$, while in July it exceeds $+18.1^{\circ} \mathrm{C}(1971$ $2000 \mathrm{IMiGW}$ a, b). Precipitation is rather not profuse equalling 500-600 mm annually (1971-2000 IMiGW a, b; Lorenc, 2005). During the vegetation period that lasts 124 days on average between 160 and $220 \mathrm{~mm}$ of rain is noted. Soils are mostly poor and were formed on fluvial sands of riverbeds (www.warszawa.lasy.gov.pl).

\section{Data processing}

According to EKO strategy of dendrochronological studies (Zielski and Krąpiec, 2004), the selection of study sites guided by the principle of uniformity of growth conditions has been applied. Besides, to reach the goal of this study, only dominant, healthy and undamaged trees were sampled, because only such trees can be useful in determining the impact of climatic conditions on tree ring growth, therefore its allows to exclude the impact of anthropogenic and other non-climatic factors. A total number of 10-20 trees from each study site sufficiently represent the local dendrochronological signal. One increment core per tree was taken using a Pressler borer. The obtained material was prepared following standard procedures (Cook and Kairiukstis, 1990) and scanned. Tree-ring widths were measured on the increment cores with BP-Biotronic device to the accuracy of $0.01 \mathrm{~mm}$.

Elaborated tree-ring width series were cross-dated visually using standard dendrochronological techniques (Cook and Kairiukstis, 1990). Quality of cross-dating was statistically checked with COFECHA program (Holmes, 1999; Grissino-Mayer, 2001). The series that showed evident dissimilarity were excluded from further analysis 
as they might limit the common signal in the chronology. Altogether series representing 107 trees were used to build the chronologies (Fig. 3). The obtained statistics of the elaborated chronologies show that they represent the common signal quite well as the mean Rbar is rather high (Table 1) and expressed population signal (EPS) values exceed critical level of 0.85 for the majority of the series time span (except Pultusk) (Fig. 2). The expressed population signal describes the degree to which the particular chronology expresses the theoretical population chronology (Mäkinen and Vanninen 1999). For all sites the GLK coefficient (Table 3), explaining the compatibility of tree rings growth, was calculated (Eckstein and Bauch, 1969).

\section{Dendroclimatological analyses}

To pronounce climate-related high-frequency signal and to minimise long-term age-dependent trend, each tree ring width series was standardised in the two-staged detrending process using the negative exponential curve and the linear regression function (Fritts, 1976; Cook and Kairiukstis, 1990). In the next step, the indices were prewhitened using an autoregressive model selected, following the minimum of AIC and averaged across all series using bi-weight robust estimation of the mean (Cook, 1985). Standard and residual chronologies were computed for all sites with CRONOL software (Holmes, 1999).

DendroClim2002 (Biondi and Waikul, 2004) software was used to investigate the influence of climate on the growth of analysed oaks. The program utilises the response function concept (Fritts, 1976) that connects tree- ring width (dependent variable) and climatic predictors (independent variables) in multivariate correlationregression model. The analysis included residual oak chronologies (Fig. 3) as well as thermal and pluvial conditions spanning from April of the previous growth year to September of the current growth year (18 months altogether). For each month in the June-August period simple water availability index was calculated by dividing monthly sum of precipitation by mean temperature. In the next step, individual values of this index were subtracted from the 1901-2000 average constituting the series of derivatives, which was later on correlated with the treering chronology representing individual study sites. Climate data used in the study originates from the CRUTS 2.1 set (Mitchell and Jones, 2005). Significance of analysed relationships was assessed at the 0.05 level.

As extreme environmental factors are supposed to cause the formation of exceptionally wider or narrower tree ring as the response to unusually favourable or unfavourable conditions (Fritts, 1976; Schweingruber, 1996), pointer year analysis was carried out to determine situations when conspicuously smaller or larger increment was formed. 'Normalisation-in-the-moving-window' procedure (Cropper, 1979) was applied. A given year was considered as a pointer one when at least $80 \%$ of trees from individual site exhibited the same (positive or negative) extreme type of increment reaction. Calculations were performed in WEISER program (Gonzales, 2001) for 5-years-long window.

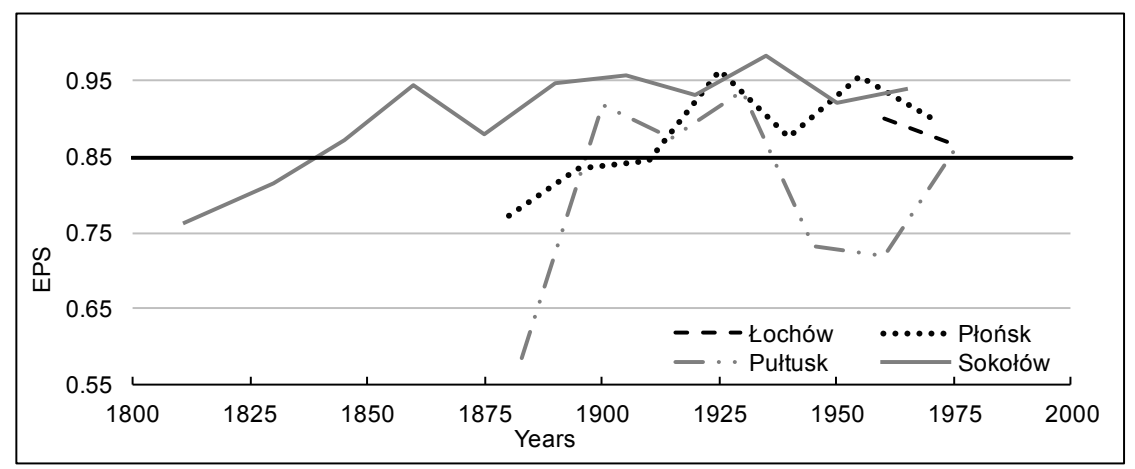

Fig. 2. Running EPS values for tree-ring width series of oaks for analyzed study sites. The black vertical line indicates the 0.85 threshold.

Table 1. Basic statistical characteristics of oak chronologies from study sites.

\begin{tabular}{|c|c|c|c|c|c|c|c|}
\hline Forest District & Interval & Years & Mean & Standard deviation & Mean sensitivity & Autocorrelation & Mean Rbar \\
\hline & \multicolumn{7}{|c|}{ tree-ring chronology } \\
\hline Lochów & 1927-1992 & 66 & 2.43 & 0.53 & 0.16 & 0.6 & 0.43 \\
\hline Płońsk & 1845-1992 & 148 & 1.86 & 0.66 & 0.22 & 0.74 & 0.5 \\
\hline Pultusk & 1868-1992 & 125 & 1.9 & 0.95 & 0.2 & 0.86 & 0.53 \\
\hline Sokołów & 1796-1992 & 197 & 1.85 & 0.61 & 0.2 & 0.72 & 0.69 \\
\hline
\end{tabular}


a)

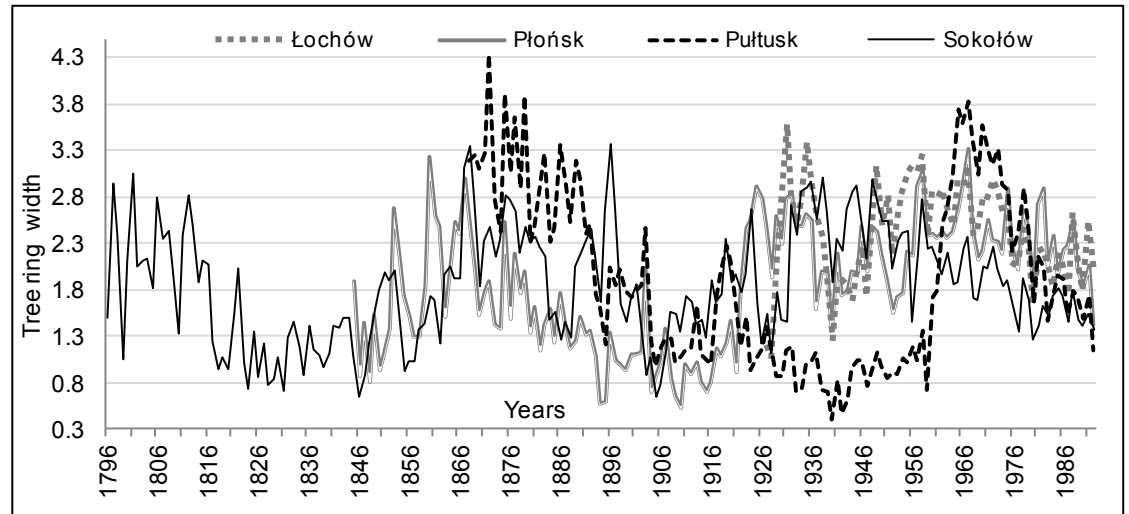

b)

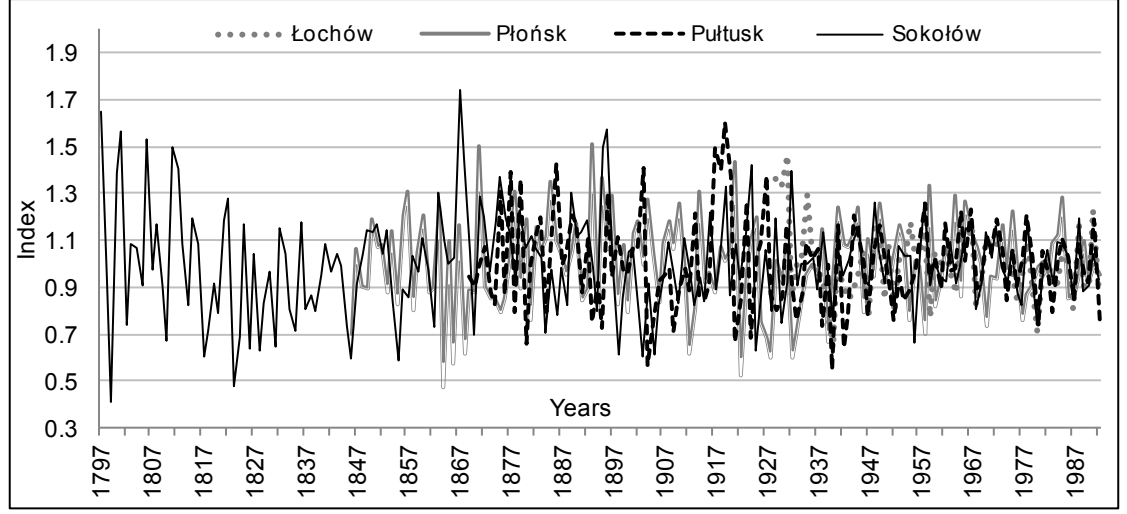

Fig. 3. Tree-ring width series (a) and residual (b) chronologies of oaks from analysed study sites.

\section{RESULTS}

Elaborated chronologies that present radial mean treering widths spanned from $1.85 \mathrm{~mm}$ (Sokołów) to $2.43 \mathrm{~mm}$ (Lochów) and standard deviations of raw measurements varied from 0.53 to $0.95 \mathrm{~mm}$ (Table 1). All analysed chronologies show rather moderate similarity, as calculated values of GLK index amounted to $63-70 \%$. Mean sensitivity of constructed raw chronologies equalled 0.16 (Łochów), 0.20 (Pułtusk, Sokołów) and 0.22 (Płońsk). As for standard and residual chronologies this parameter describes vulnerability of the analysed trees to be influenced by climate conditions. Obtained values of mean sensitivity confirm grounds of applying the constructed chronologies in climate-increment analyses.

The radial increment of oaks in Łochów Forest District significantly depends on thermal conditions in August of the year prior to tree-ring formation. The temperature in July and August (previous year) as well as in June (the year of ring development) is important in the Płońsk Forest District. In the Pułtusk Forest District significant dependence is observed only for previous August. June (year of ring development) is a month which is reflected by significant temperature influence in the Sokołów Forest District (Fig. 4a). All of these relationships are negative, which means that high temperature in summer is not a favourable factor influencing the increment of the analysed trees. In turn, temperature in September of the year of tree-ring formation was of significant positive importance in case of the Sokołów Forest District. Warm end of the vegetation season results in wider rings in that area (Fig. 4a). Positive correlation between tree-ring width and the sum of precipitation reveals great moisture demand of analysed trees during the process of increment formation. Such relationship was observed for the Lochów, Płońsk and Pułtusk Forest Districts (Fig. 4b). Positive influence of precipitation was recorded for June and July (Pultusk), August (Płońsk, Pułtusk) and November (Łochów) of the year prior to growth. In year of tree-ring formation significant correlation was observed for June (Płońsk, Pułtusk) and August (Pułtusk). No significant relationship between radial increment and precipitation was detected for oaks in Sokołów Forest District (Fig. 4b).

Analysis of the influence of water availability in the June-August period revealed strong dependence of radial growth of investigated oaks on that factor. The strongest relation was found for June (Fig. 5). Water shortage very often resulted in narrow rings and, in contrary, increased water availability went with wider increment. For example, years 1936-1942 was quite dry at all investigated sites and growth depressions and very narrow ring can be noticed in all oak chronologies. In turn, very wet year 1947 resulted in a large tree-ring. 
Altogether 18 individual negative (13) and positive (5) pointer years were determined (Table 2). Especially wide tree-ring was formed in 1967 in the Płońsk and Sokołów Forest Districts. 1941 and 1982 were positive pointer years for Płońsk site. For the Łochów Forest District positive pointer year was 1991. Very narrow increments can be observed in 1940 and 1952 (Lochów, Płońsk) as well as in 1992 (Płońsk, Pułtusk) and 1969 for the Sokołów and Pułtusk Forest Districts.

Table 2. Pointer years of analysed oaks.

\begin{tabular}{ccccc}
\hline & Lochów & Płońsk & Pultusk & Sokołów \\
\hline \multirow{2}{*}{ negative } & $\begin{array}{c}1940,1947,1952, \\
1959,1976,1980, \\
1987\end{array}$ & $\begin{array}{c}1940,1952, \\
1992\end{array}$ & 1969,1992 & 1969 \\
\hline positive & 1991 & $\begin{array}{c}1941,1967, \\
1982\end{array}$ & 1967 \\
\hline
\end{tabular}

\section{DISCUSSION}

Mean tree-ring width of analysed oaks is similar to the values reported in studies from other areas in Poland. Ważny and Eckstein (1991) obtained results from $0.83 \mathrm{~mm}$ (Wolin, NW Poland) to $2.33 \mathrm{~mm}$ (Gołdap, NE Poland). Ufnalski (2001) reports 1.42 and $1.53 \mathrm{~mm}$ for sessile and pedunculate oak, respectively. Mean tree-ring width from north-eastern Poland presented by Krapiec and Szychowska-Krąpiec (2004) varied from 1.59 to $2.31 \mathrm{~mm}$. Cedro (2004) obtained $1.59 \mathrm{~mm}$ for sites in

Table 3. GLK coefficient for all analyzed sites.

\begin{tabular}{c|c|c|c}
\hline Lochów & Płońsk & Pułtusk & Sokołów \\
\hline Lochów & $65 \%$ & $70 \%$ & $70 \%$ \\
\hline & Płońsk & $66 \%$ & $68 \%$ \\
\hline & & Pułtusk & $63 \%$ \\
\hline
\end{tabular}

a)

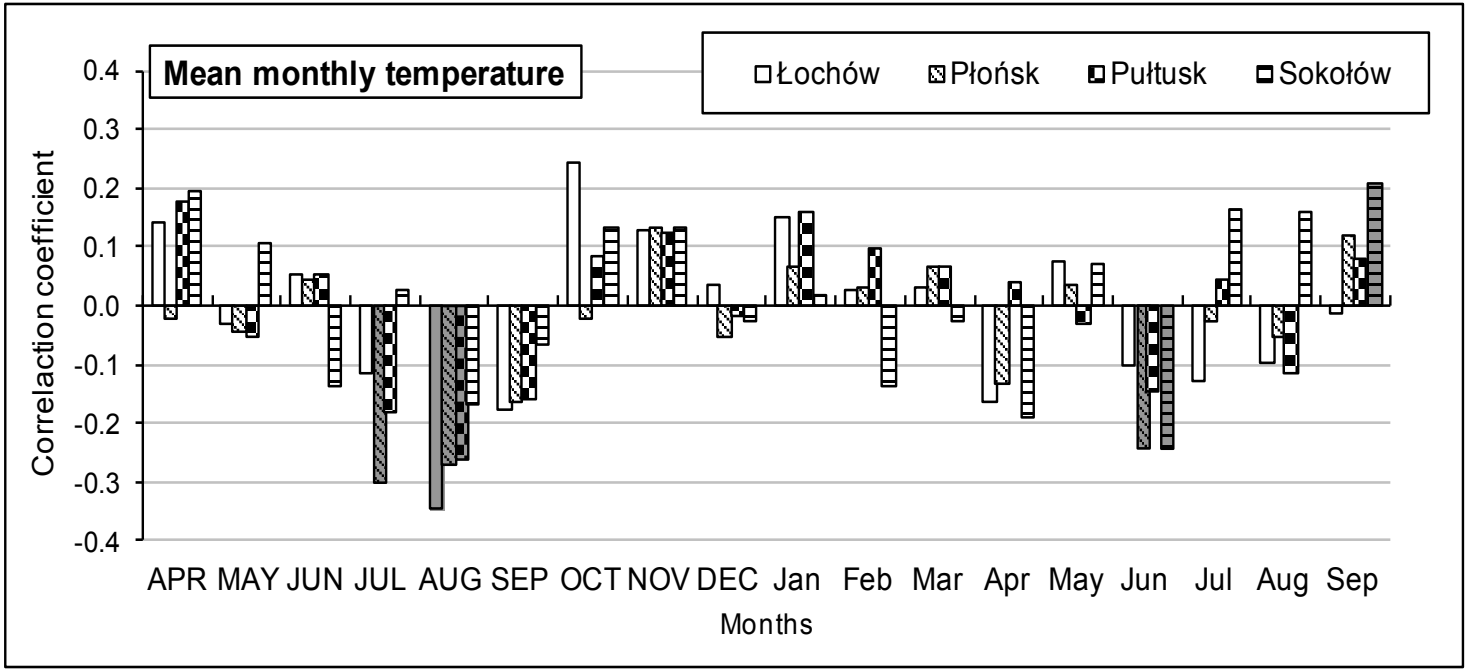

b)

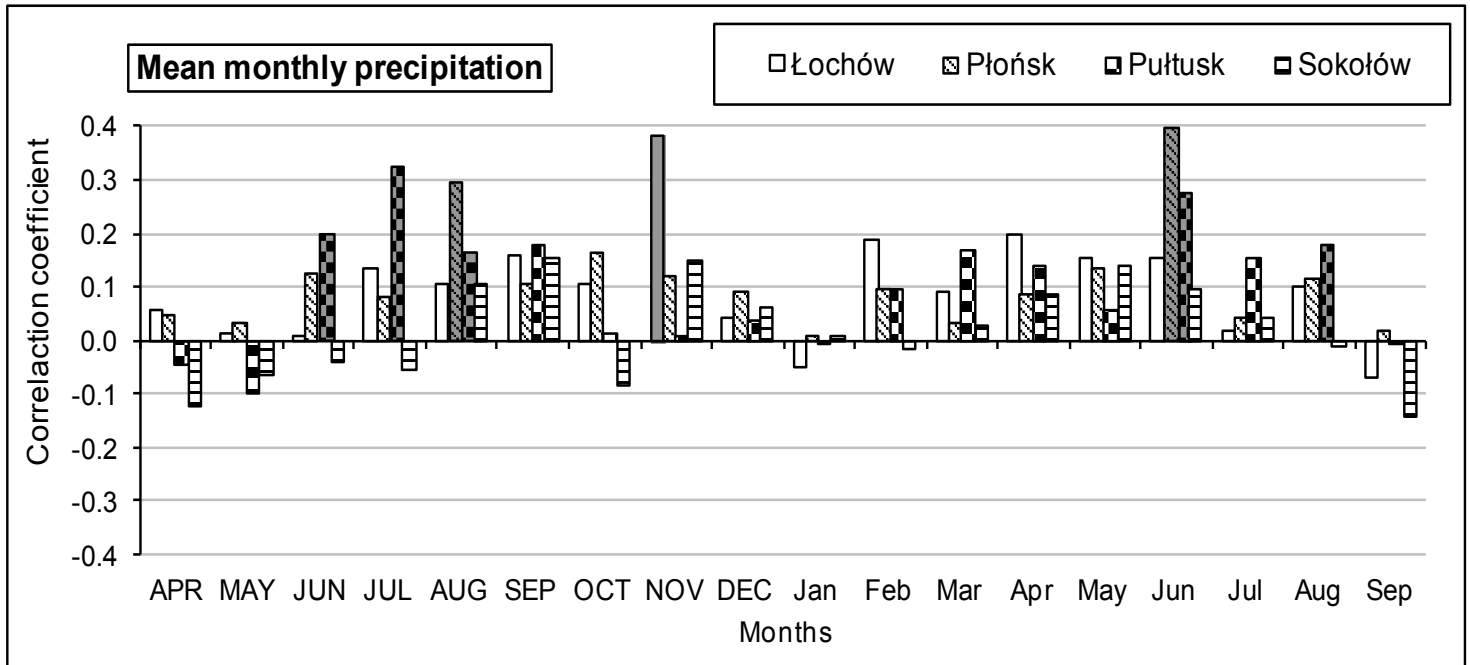

Fig. 4. Impact of mean monthly temperature (a) and precipitation (b) on growth of oaks from analysed study sites - correlation coefficients. Shaded bars indicate values significant at 0.05 level, capital letters - year prior to ring formation. 

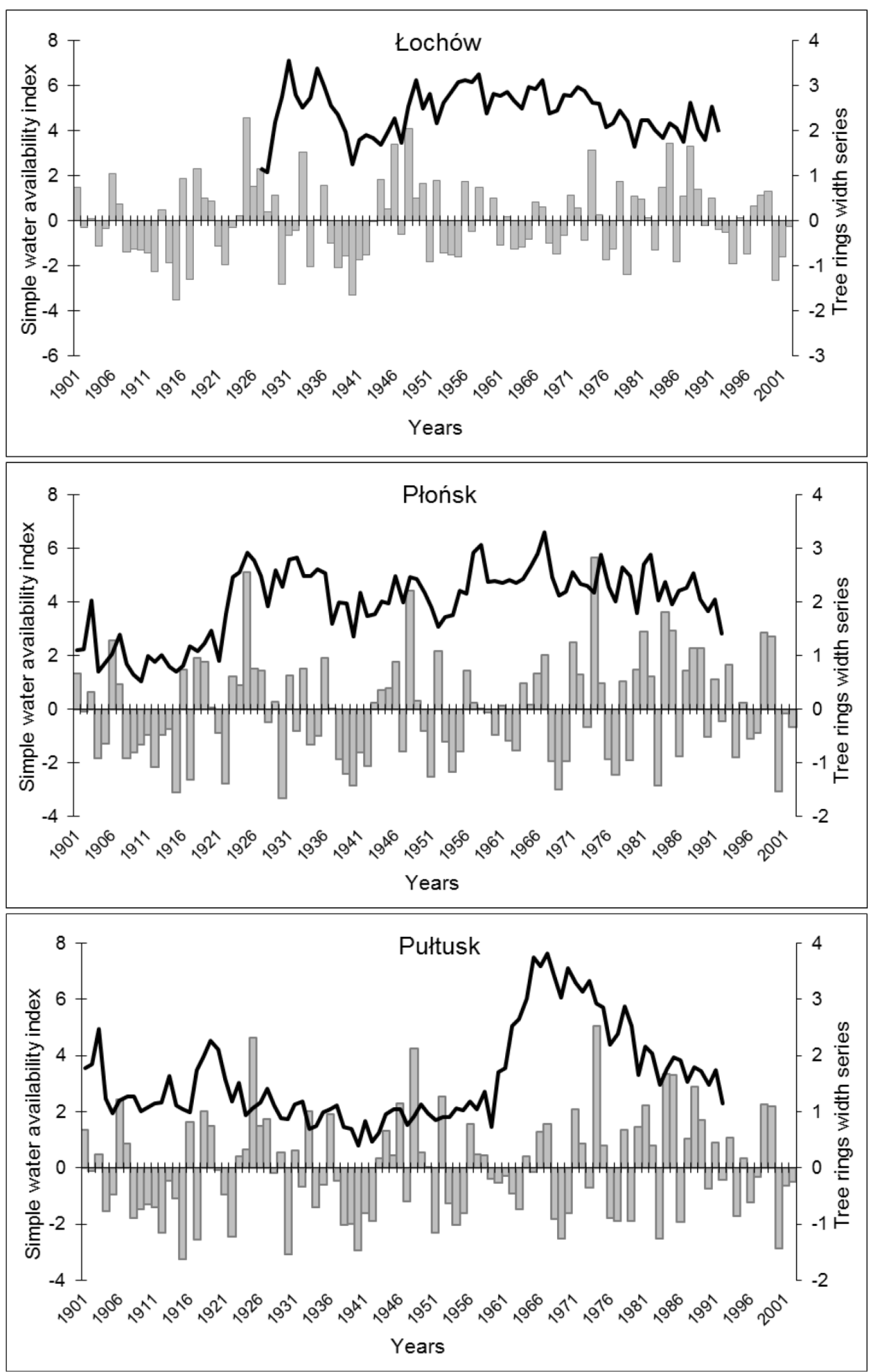

Fig. 5. Dependence of oak annual increment (right scale, black line - tree ring chronology) on water availability (left scale, grey bars) in June. 


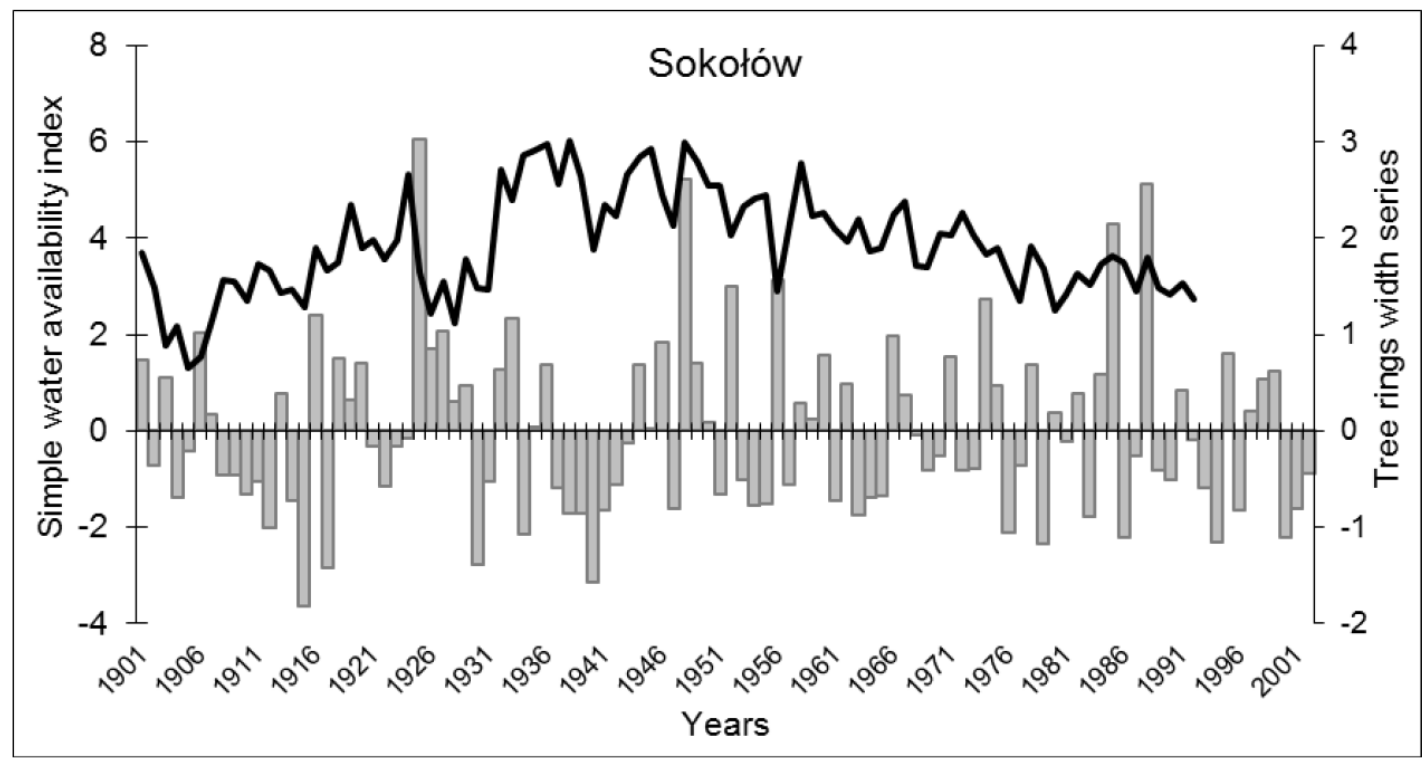

Fig. 5. Continuation.

the Pomorze Zachodnie region. In the Bielinek reserve (NW Poland) mean ring widths changed from 1.09 to $1.48 \mathrm{~mm}$ (Cedro, 2007).

Results presented in the analyses conducted to date confirm a negative temperature influence on radial increment of oaks. Ermich (1953) already reported such conclusion. Also, Ważny and Eckstein (1991) show that as far as oaks from different localities in Poland are concerned, temperature has a negative influence, but quite evidently analysed oaks prefer mild winters. Ufnalski (2001) found that thermal conditions in August and October of the year prior to ring formation have a negative influence on that process. In turn, Cedro (2004) reported negative correlation between tree-ring width and temperature in July and August of the previous year in northwestern Poland. Similar observations were made for downy, sessile and pedunculate oaks in the Bielinek Natural Reserve (NW Poland). Additionally, the same type of relationship was found for May and June of the year of ring formation (Cedro, 2007). This negative influence of temperature on radial increment of oaks is also mentioned in many studies over Europe. Rozas (2001) and Santini et al. (1994) found it for July analysing factors shaping growth of Quercus robur L. in northern Spain. Tessier et al. (1994) report such relationship for May-July in the Mediterranean region. Also in case of oaks growing in the Netherlands heat in summer results in formation of a narrower ring next year (van der Werf et al., 2007). In turn, Tardif and Conciatori (2006) observed negative influence of temperature of previous May on the growth of white and red oaks in Quebec (Canada). A positive correlation with temperature was found for the Niepołomice Forest, where Bednarz and Ptak (1990) observed that a warm end of summer (August) favours wider rings. Similar results were shown in Szczepanek et al. (2006) where the authors describe the correlation between isotopes in the annual growth and climatic factors. Analogous pattern occurs at the Sokołów site. In that case positive influence of temperature is for September (Fig. 4a). Cedro (2004), as well as Gray and Pilcher (1983), report the same type of relationship for October of the year prior to ring formation.

Positive character of the relationship between radial increment of the analysed oaks and summer precipitation suggests their vulnerability to moisture deficit during the vegetation period. Such observation is confirmed by many studies in Poland and Europe. According to Ważny and Eckstein (1991), growth of Polish oaks is positively dominated by precipitation, especially from April to August. Bednarz (1994) points out the importance of MayJuly rainfall for the process of tree-ring formation of oaks in the Niepołomice Forest. Ermich (1953) reports positive correlation between tree-ring width and June precipitation. He claims that this is the time of the most intensive radial growth and oaks may produce up to $35 \%$ of annual wood production. Ufnalski (2001) and Cedro (2004) present similar conclusions. In the Bielinek Nature Reserve positive increment reaction to precipitation occurred in October and December of the year preceding the growing period and April of the current period were of influence; the relationships were extremely strong in February and June (Cedro, 2007). Dependence of oak growth on summer precipitation was also found in studies in different places in Europe. Rozas (2001) reports positive correlation of June precipitation and increment of Spanish oaks. Santini et al. (1994) in Tuscany (Italy), as well as Gray and Pilcher (1983) in the United Kingdom, received comparable relationship for May-July precipitation. In the Mediterranean area the same was observed for May-August period (Tessier et al., 1994). Van der Werf 
et al. (2007) found positive character of growth of Dutch oaks-precipitation relationship for previous December and current March. Oaks from Canada also favoured wet June (Tardif and Conciatori, 2006).

Extreme increment reactions of oaks from Łochów, Płońsk, Pułtusk and Sokołów show slight similarity to those reported for other regions. Narrow rings observed at these sites in years 1952, 1959, 1969 and 1992 turned out to be also negative pointer years at seven study sites analysed by Ufnalski (2001) and in the Bielinek Nature Reserve (Cedro 2007). The results of the presented research correspond with that of Boryczka et al. (2007), especially as far as eastern Poland is concerned. Corresponding negative pointer years of oak were determined for Suwałki (1940, 1947, 1969 and 1976). The narrow ring of 1940 was also found in oaks growing in Gołdap (NE Poland) as well as Poznań and Wrocław (W Poland). Year 1947 was observed in Warszawa and Wrocław chronologies. Those narrow rings are probably a result of insufficient precipitation during the growing season. Weber et al. (2005) and Eilmann et al. (2006) discussed such drought vulnerability of oaks. As Ważny and Eckstein (1991) noticed, such country-wide signature years for Poland are e.g. 1800, 1940 and 1952. All can be explained by unfavourable climate conditions. The same reason of narrow rings, but in different years, was reported by Čufar et al. (2008) and Büntgen et al. (2011). Inglot (1968) found that narrow ring of 1800 was caused by a drought in the previous year. In 1940 there was an extremely cold winter with subsequently little precipitation and in 1952 trees suffered from a preceding dry autumn and winter. Harsh winter followed by a dry summer was observed in 1940, 1947, 1952, 1962, 1976, 1980 and 1987. Such situation was also reported by Mager et al. (1999). In years 1941, 1967, 1982 and 1991 analysed oaks produced very wide rings. Pointer years determined for the analysed sites correspond with some extent to those found for whole Poland by Boryczka et al. (2007). Probable cause of production of so wide tree rings in those years may lay in profuse rainfall in spring-summer time, as suggested by Cedro (2004).

\section{CONCLUSIONS}

The analysed oaks from sites in central Poland exhibit a growth pattern comparable with ones known from previous studies concerning that species. Also, relationships between tree-ring widths and basic climate variables are similar (temperature - negative, precipitation - positive). Extreme growth reactions expressed by negative and positive pointer years in general correspond to one observed on other sites in Poland.

\section{REFERENCES}

Bednarz Z, 1987. A 225-year tree-ring chronology of oak Quercus robur L. in the Niepołomice Forest near Kraków. Dendrochronologia 5: 59-68.

Bednarz Z and Ptak J, 1990. The influence of temperature and precipitation on ring widths of oak (Quercus robur L.) in the Niepołomice Forest near Cracow, Southern Poland. Tree-Ring Bulletin 50: 1-10.

Bednarz Z, 1994. Niedobory wody przyczyną depresji przyrostowych u dębu (Quercus robur L.) w Puszczy Niepołomickiej (Water deficit limits tree-ring widths of the Oak (Quercus robur L.) in the Niepołomice Forest, Southern Poland). Sylwan 138(10): 29-39 (in Polish).

Bijak Sz, 2009. North Atlantic Oscillation signal in tree-rings of oak in Poland. In: Kaczka RJ et al., eds., TRACE - Tree Rings in Archeology, Climatology and Ecology 7: 28-35.

Biondi F and Waikul K, 2004. DendroClim2002: A C++ program for statistical calibration of climate signals in tree-ring chronologies. Computers and Geosciences 30(3): 303-311, DOI 10.1016/j.cageo.2003.11.004.

Boratyńska K, Filipiak M and Boratyński A, 2006. Budowa morfologiczna i zmienność (Morphological characteristics and variability). In: Bugała W, ed., Dęby Nasze Drzewa leśne 11. Bogucki Wydawnictwo Naukowe, Poznań-Kórnik: 63-84 (in Polish).

Boryczka J, Stopa-Boryczka M, Bijak Sz, Cebulski R, Błażek E and Skrzypczuk J, 2007. Atlas wspólzależności parametrów meteorologicznych i geograficznych w Polsce cz. XX-XXI Cykliczne zmiany klimatu Europy $w$ ostatnim tysiacleciu wedtug badań dendrologicznych (Atlas of correlations between meteorological and geographical parameters in Poland pt. 20-21. Cyclic changes of European climate in last millennium according to dendrological research). Wydawnictwo Uniwersytet Warszawski, Warszawa (in Polish).

Bruchwald A and Dmyterko E, 1999. Reakcja przyrostowa dębu w powiązaniu ze stopniem uszkodzenia korony (Growth response of oak as connected with the crown damage level). Sylwan 2: 47-57 (in Polish).

Büntgen U, Tegel W, Nicolussi K., McCormick M, Frank D, Trouet, V, Kaplan J, Herzig F, Heussner U, Wanner H, Luterbacher J and Esper J, 2011. 2500 years of European climate variability and human susceptibility. Science 331: 578-582, DOI 10.1126/science. 1197175 .

Cedro A, 2004. Zmiany klimatyczne na Pomorzu Zachodnim w świetle analizy sekwencji przyrostów rocznych sosny zwyczajnej, daglezji zielonej i rodzimych gatunków dębów (Climatic changes in Western Pomerania basing on the analysis of tree-ring sequences of Scots pine, Douglas fir and native species of oak). $\mathrm{PhD}$ thesis, the University of Szczecin (in Polish).

Cedro A, 2007. Tree-ring chronologies of downy oak (Quercus pubescens $)$ pedunculate oak $(Q$. robur $)$ and sessile oak $(Q$. petraea $)$ in the Bielinek Nature Reserve: comparison of the climatic determinats of tree-ring width. Geochronometria 26: 29-45. DOI 10.2478/v10003-007-0005-2.

Cook ER, 1985. A time series analysis approach to tree-ring standardization. PhD thesis, University of Arizona.

Cook ER and Kairukstis LA, 1990. Methods of dendrochronology: applications in the environmental sciences. IIASA, Kluwer Academic Publishers, Boston.

Cropper JP, 1979. Tree-ring skeleton plotting by computer. Tree-ring Bulletin 39: 47-59.

Čufar K, de Luis M, Eckstein D and Kajfez-Bogataj L, 2008. Reconstructing dry and wet summers in SE Slovenia from oak tree-ring series. International Journal of Biometeorology 52(7): 607-615, DOI 10.1007/s00484-008-0153-8.

Dekadowy Biuletyn Agrometeorologiczny 2001-2002, IMiGW a. Instytut Meteorologii i Gospodarki Wodnej, Warszawa.

Biuletyn Państwowej Stużby Hydrologiczno-Meteorologicznej 20032007, IMiGW b. Instytut Meteorologii i Gospodarki Wodnej, Warszawa. 
Desprez-Loustau ML, Marcais B, Nageleisen LM, Piou D and Vannini A, 2006. Interactive effects of drought and pathogens in forest trees. Annals of Forest Science 63(6): 597-612, DOI 10.1051/forest:2006040.

Eckstein D and Bauch J, 1969. Ein Beitrag zur Rationalisierung eines dendrochronologishen Verfahrens und zur Analyse seiner Aussagesicherheit. Forstwiss. Centralbl. 88: 230-250.

Eilmann B, Weber P, Rigling A and Eckstein D, 2006. Growth reactions of Pinus sylvestris L. and Quercus pubescens Willd. to drought years at a xeric site in Valais, Switzerland. Dendrochronologia 23(3): 121-132, DOI 10.1016/j.dendro.2005.10.002.

Ermich K, 1953. Wpływ czynników klimatycznych na przyrost dębu szypułkowego (Quercus robur L.) oraz sosny zwyczajnej (Pinus silvestris L.) próba analizy zagadnienia. (The influence of climatic conditions on growth of Quercus robur and Pinus sylvestris). Prace Rolniczo-Leśne PAU 68: 1-61 (in Polish).

Ermich K, 1959. Badania nad sezonowym przebiegiem przyrostu grubości pnia u Pinus sylvestris L. i Quercus robur L (Studies on the seasonal course of growth of Pinus sylvestris $\mathrm{L}$ and Quercus robur L.). Acta Societatis Botanicorum Poloniae 28: 15-63 (in Polish).

Fritts HC, 1976. Tree rings and climate. Academic Press, London-New York-San Francisco.

Gonzalez IG, 2001. Weiser: a computer program to identify event and pointer years in dendrochronological series. Dendrochronologia 19(2): 239-244.

Gray BM and Pilcher JR, 1983. Testing the significance of summary response functions. Tree-Ring Bulletin 43: 31-37.

Grissino-Mayer HD, 2001. Evaluating cross-dating accuracy: a manual and tutorial for the computer program COFECHA. Tree Ring Research 57: 205-221.

Holmes RL, 1999. Dendrochronology Program Library (DPL) Users Manual. LTRR University of Arizona, Tucson.

Ingot S, 1968. Zjawiska klimatyczno-meteorologiczne na Śląsku od XVI do połowy XIX wieku (Climatic events in Silesia from the 16th to the middle of the 19th century). In: Swiettochowski B, ed., $Z$ badań nad wplywem posuchy na rolnictwo na Dolnym Ślasku. PWN, Wrocław: 9-29 (in Polish).

Krąpiec M, 1998. Oak dendrochronology of the Neoholocene in Poland. Folia Quaternaria 69: 5-133.

Krąpiec M, 2001. Holocene dendrochronological standars for subfossil oaks from the area of Southern Poland. Studia Quaternaria 69: 135-150.

Krąpiec M and Szychowska-Krapiec E, 2004. Standardy dendrochronologiczne sosny zwyczajnej (Pinus sylvestris L.) i dębu szypułkowego (Quercus robur L.) z północno-wschodniej Polski (Dendrochronological standards of Scots pine (Pinus sylvestris L.) and English oak (Quercus robur L.) from north-eastern Poland). Sylwan 148 (7): 11-19 (in Polish).

Lebourgeois F, Cousseau G and Ducos Y, 2004. Climate-tree-growth relationships of Quercus petraea Mill. stand in the Forest of Bercé ('Futaie des Clos', Sarthe, France). Annals of Forest Science 61(4): 361-372, DOI 10.1051/forest:2004029.

Lorenc H, ed., 2005. Altas klimatu Polski. Instytut Meteorologii i Gospodarki Wodnej, Warszawa (in Polish).

Mager P, Kuźnicka M, Krępińska-Kasprzak M and Farat R, 1999. Zmiany natężenia i częstotliwości pojawiania się susz w Polsce (1891-1995) (Changes in intensity and frequency of occurrence of droughts in Poland (1891-1995)). Proceedings of the conference Zmiany i zmienność klimatu Polski: 156-164 (in Polish).

Mäkinen H and Vanninen P, 1999. Effect of sample selection on the environmental signal derived from tree-ring series. Forest Ecology and Management 113(1): 83-89, DOI 10.1016/S03781127(98)00416-2.
Methy M, Damesin C, Rambal S, 1996. Drought and photosystem II activity in two Mediterranean oaks. Annals of Forest Science 53(23): 255-262, DOI 10.1051/forest:19960208.

Mitchell TD and Jones P, 2005. An improved method of constructing a database of monthly climate observations and associated highresolution grids. International Journal of Climatology 25(6): 693712 , DOI $10.1002 /$ joc. 1181.

Pilcher JR and Gray B, 1982. The relationships between oak tree growth and climate in Britain. Journal of Ecology 70(1): 297-304.

Rozas V, 2001. Detecting the impact of climate and disturbances on tree-rings of Fagus sylvatica L. and Quercus robur L. in a lowland forest in Cantabria, Northern Spain. Annals of Forest Science 58(3): 237-251, DOI 10.1051/forest:2001123.

Santini A, Bottacci A and Gellini R, 1994. Preliminary dendroecological survey on pedunculate oak (Quercus robur L) stands in Tuscany, Italy. Annales des Sciences Forestieres 51(1): 1-10, DOI 10.1051/forest: 19940101 .

Szczepanek M, Pazdur A, Pawełczyk S, Böttger T, Haupt M, Hałas S, Bednarz Z, Krąpiec M and Szychowska-Krąpiec E, 2006. Hydrogen, carbon and oxygen isotopes in pine and oak tree rings from Southern Poland as climatic indicators in years $1900-2003$. Geochronometria 25: 67-76.

Schweingruber FH, 1996. Tree rings and environment. Paul Haupt, Bern.

Siwecki R, 1994. Globalne zmiany klimatyczne a zamieranie debów (Oaks' decline related to global climate change). Sylwan 138(10): 43-59 (in Polish).

Tardif JC and Conciatori F, 2006. A comparison of ring-width and event-year chronologies derived from white oak (Quercus alba) and northern red oak (Quercus rubra), Southwestern Quebec, Canada. Dendrochronologia 23(3): 133-138, DOI 10.1016/j.dendro.2005.10.001.

Tessier L, Nola P and Serre-Bachet F, 1994. Deciduous Quercus in the Mediterranean region: tree-ring/climate relationships. New Phytologist 126(2): 355-367, DOI 10.1111/j.1469-8137.1994.tb03955.x.

Ufnalski K, 2001. Porównanie dynamiki przyrostu dębu szyputkowego i bezszyputkowego ze szczególnym uwzględnieniem okresów zamierania (Comparisson of growth of pedunculat and sessile oaks with special regard to decline periods). $\mathrm{PhD}$ thesis, Institute of Dendrology Polish Academy of Sciences (in Polish).

Van der Werf GW, Sass-Klassen UGW and Mohren GMJ, 2007. The impact of the 2003 summer drought on the intra-annual growth pattern of beech (Fagus sylvatica L.) and oak (Quercus robur L.) on a dry site in the Netherlands. Dendrochronologia 25(2): 103112, DOI 10.1016/j.dendro.2007.03.004.

Vannini A, Valentini R and Luisi N, 1996. Impact of drought and Hypoxylon mediterraneum on oak decline in the Mediterranean region. Annals of Forest Science 53(2-3): 753-760, DOI 10.1051/forest: 19960251.

Ważny T, 1990. Aufbau und Anwendung der Dendrochronologie fur Eichenholz in Polen. Phd thesis, Universitaet Hamburg (in German).

Ważny T, 2006. Dendrochronologia dębu (Dendrochronology of oak). In: Boratyński A, ed., Deby. Ouercus robur L. Ouercus petraea (Matt.) Nasze drzewa leśne. Monografie Popularnonaukowe, Poznań-Kórnik: 39-61 (in Polish).

Ważny T and Eckstein D, 1991. The dendrochronological signal of oak (Quercus spp.) in Poland. Dendrochronologia 9: 35-49.

Weber P, Rigling A and Bugmann H, 2005. Differences in drought response of Pinus sylvestris L. and Quercus pubescens Willd. in the Swiss Rhone valley. In: Jansma E, Brauning A, Gartner H, Schleser G, eds., TRACE 2: 48-52.

Zielski A and Krąpiec M, 2004. Dendrochronologia (Dendrochronology). Wydawnictwo Naukowe PWN Warszawa (in Polish). 